\title{
POLANYIAN LESSONS FOR OUR DAYS: THE CASE OF BRAZIL
}

Karl Polanyi is considered one of the leading thinkers of the twentieth century in the fields of Economics, History, Anthropology and Sociology. For him, the object of Economics was to understand how human beings organize themselves as to deal with the material aspects of their lives; accordingly, he studied such subjects as the markets, trade and other economic institutions, trying to understand how they affect our lives.

Born at the end of the XIX Century in Vienna, and raised in Budapest, Polanyi's experience of the conflicts of the Central Europe of his youth, later reinforced by his years as an exiled intellectual in the England of the 1930's, led him to propose that the convulsion that was shaking that world during those years was a reaction against a new (and very problematic) form of organization of the human society: the market society. In his understanding, although markets certainly were not a novelty, they had always occupied a restricted space in human life. However, since the Industrial Revolution they had moved to the forefront and turned the society into an accessory of the markets, and the crisis begun with the First World War was a reaction against this unnatural situation.

Polanyi wrote some very important books about a wide variety of subjects in economic history. In all of them is clear his concern to show, through contrasts and comparisons, the specificity of the capitalist economies. One of his books, The Great Transformation, is considered not only his main work, but also one of the most important books in the social sciences in the past century ${ }^{1}$. Polanyi analyzes in this book, in his unique style, the social consequences of the economic organization that characterized the societies of the XIX century. Some central insights of this book represent the first formulations of the basic agreements of the substantivist school ${ }^{2}$, which maintains that the study of the economic aspects of any society should stress the role of its culture, its institutions and its history; or, to put it in Polanyi's terms, should recognize that the economy is embedded in the society.

The impact of the work of Polanyi goes well beyond his life and his work. His main insights are lively discussed nowadays ${ }^{3}$. Contemporary scholars apply his main insights both to the research about Ancient Economies (e.g., Tandy, 2001), as well as on the contemporary ones (e.g., Adaman \& Devine, 2002) $)^{4}$.

This paper will follow this last approach, trying to apply his basic insights to understand the evolution of Brazilian society, especially looking at the development and present situation of the of the markets for what he called the three fictitious commodities, land, labor and money. To do this, the paper is structured in three sections. In the first one, we discuss Polanyi's worldview, searching for the main motivations of his work. In section II, we discuss the work of some scholars that in the last two decades

\footnotetext{
${ }^{1}$ Rather surprisingly, it was included in the list “One hundred most influential books since World War II” on the Oct 6, 1995 issue of The Times Literary Supplement.

${ }^{2}$ Polanyi's perspective has also a strong link with the original institutionalist school, and he can be considered as one of its members. One of Polanyi's most important students, Walter Neale, became a leading figure of the Association for Evolutionary Economics.

${ }^{3}$ One of the main institutions promoting works along these lines is the Karl Polanyi Institute of Political Economy, founded in 1987 and based in Concordia University, in Montreal, Canada, and created “...in response to the growing recognition of the relevance of Karl Polanyi's work to contemporary society”, according to its homepage, http://artsandscience.concordia.ca/polanyi/ (access on April 15, 2007).

${ }^{4}$ In Brazil, however, there has not been recently much discussion based on Polanyi's perspectives. Some exceptions we can mention are Lisboa (2000), Garlipp (2006) and Wjuniski \& Fernandez (2008).
} 
worked within a Polanyian perspective to understand the contemporary problemsof mankind. Following their lead, in the third section of the paper we make a still preliminary discussion of the evolution of the markets for the three fictitious commodities in Brazil. Some conclusions follow.

\section{I - Polanyi's worldview}

To understand the contemporary significance of Polanyi's ideas, we initially need to present some fundamental concepts developed by him in his most important works, which represent an important part of his legacy. Because of their impact inside and outside the academy, these concepts are still discussed and employed in our days. This is the objective of this section, to present and discuss Polanyi's worldview.

The Great Transformation (Polanyi, 2001) can be considered the most important work of Polanyi. In this book he discusses the economic and social implications of the industrial revolution. Its fundamental thesis is that the evolution of capitalism and the industrial revolution occurred together with a combination of two important forces: the development of the self regulating market and the consolidation of the liberal creed that was to be the cornerstone of the policies of the modern state. According to him, the consequences of the evolution of these two forces have disruptive social implications (Humphreys, 1969).

The first force, the self regulating market, corresponds to the development of a complete liberal market organization in the economy. According to Polanyi, markets and the economy should be an accessory to social relations, a means to help the exchange of goods and services, but they should never replace the social relations, as it occurred during the industrial revolution and afterwards. The completely free (liberal) market has a disruptive side, because it transforms all the features of the social life into marketable goods, as reflected, for example, in the constitution of a labor market. The social consequence of this complete freedom for the market is the removal of the human side of the economic aspects of life; we can take as an example what happened in England during the 19th century, when children and women were forced to work up to 20 hours a day. So, the first force that developed together with capitalism was the evolution of this market pattern (Polanyi, 2001).

But, as these markets began to dominate the society, the social implications of this process created discontent in the lower classes. To create a protective belt around these markets, there emerged the liberal creed, safeguarded by the national states. This ideology can be considered the way found by those who benefit from the existence of the free markets to protect them, and to convince the society that it is the best imaginable economic system, and so it should be preserved. Besides, the defense of this creed by the governments was an important way to maintain the situation under control. This is the second force mentioned above (Polanyi, 2001).

These changes that occurred during the 19th century implied the destruction of the basic social order that had existed throughout all the previous and very different societies in the history of mankind. Polanyi's empirical case relied largely on the analysis of the Speenhamland laws, which he saw not only as the last attempt to preserve the traditional system of production and social order, but also as a 
self-defensive measure on the part of the society to mitigate the disruption of this violent period of economic change (Polanyi, 2001) $)^{5}$.

In this sense, Polanyi argues that the development of the modern state went side by side with the development of the self regulating markets, and that these two changes were inevitably related in history. His argument for this was that the modern state, although typically considered a shrinking one, was actually very strong as to force the changes in the social structure that made possible the birth of a competitive capitalist economy, and at the same time this economy required a strong reaction of the society to mitigate its disruptive effects. This process was called by him double movement, because one force is a reaction to the other one: the evolution of the markets and the development of the liberal creed forced the society to protect itself. In Polanyi's words:

For a century the dynamics of modern society was governed by a double movement: the market expanded continuously but this movement was met by a countermovement checking the expansion in definite directions. Vital though such a countermovement was for the protection of society, in the last analysis it was incompatible with the self-regulation of the market, and thus with the market system itself. (Polanyi, 2001, p. 136)

Together with the double movement, there is a second important idea developed by Polanyi, the concept of embeddedness. This concept is central for his theoretical framework, because it allows him to show why the organization of the economy with completely free markets is not a basic need of mankind. Block (2000, p. xxiv) explains what embeddedness means: "The term embeddedness expresses the idea that the economy is not autonomous, as it must be in economic theory, but subordinated to politics, religion, and social relations”. So, the economy is not separated from other social activities and relations, but it is part of the life of each human being. Polanyi argues that the organization of the society around self regulating markets and the emergence of their disruptive side was only possible when the economy became disembedded, something that happened only during the industrial revolution and its aftermath, a process that clashed with the way in which men dealt with the economics aspects of life.

According to Polanyi, the embeddedness was something natural for the ancient societies (same idea we explore below), and that way of organizing life still has many things to teach us, as the process of disembedding the economy had dire social consequences.

A central part of Polanyi's analysis is the development of the concept of fictitious commodities. In his view, when the markets expand so much that everything in human life becomes tradable, some important aspects of life are transformed into commodities, but they are by nature fictitious, because they do not have the qualities needed to be transacted in the market, as they are not produced to be sold. For Polanyi, the fictitious commodities are land, labor and money, things that in an embedded economy would never be allocated through the market (Polanyi, 2001). The existence of these fictitious commodities is a direct result of the (unchecked) development of the self regulating market, and its consequences are the transformation of nature and people into commodities.

Finally, and as a consequence of his analysis of the social transformations caused by the industrial revolution, Polanyi developed a strong criticism of the orthodox liberal ideology. He understood that the rise of capitalism was based on an imposed creed and on an imposed market society, both not

\footnotetext{
${ }^{5}$ These measures are typically considered as failures because they could not prevent the advancement of the markets, capitalism, etc. Interestingly, Polanyi says that these attempts actually succeeded, because they managed to slow down the pace of the changes, which were in a certain sense unavoidable, and that it was the best result they could possibly achieve.
} 
natural in human development; he argued that laissez-faire was planned, and that the double movement was a process always refueled by society and by the national states. This criticism is still discussed today, mainly with the problems raised by neo-liberalism, showing how contemporary are Polanyi's ideas.

The next section tries to apply Polanyi's insights to our contemporary world. We discuss in it some theoretic and political proposals based on his perspective.

\section{Polanyian lessons for the present}

Before Polanyi settled in the USA after World War II, his life had not been a typical one for a scholar. He had been always involved in the discussion of contemporary matters, and although his academic experience in England gave him a chance to reflect deeply on historical issues, a basically political agenda was at the center of his concerns. Block (2003) suggests that when Polanyi was writing the Great Transformation, he thought that "market societies could be fundamentally reshaped by deeply democratic reforms”. However, after writing his essay “Our Obsolete Market Mentality” (in Polanyi, 1968, originally published in 1947) he realized that he could not influence the flow of events so he shifted “..his intellectual energies toward the analysis of primitive and archaic economies” (Block, 2003, p.298). In any case, Polanyi's personal shift, dictated by the circumstances of a strong polarization in the international political arena ${ }^{6}$, did not prevent his followers from developing practical applications of his vision, as we discuss below.

\subsection{The political agenda of Karl Polanyi}

Polanyi's insights about the consequences of the industrial revolution as well as his views on the importance of the Ancient societies for our comprehension of the role of the market in the economy are part of the set of arguments that led to main debates in the mid-twentieth century about the importance of the state as a regulator of the economy. One of these political consequences was the development of the Welfare State in many parts of the world, especially in the more democratic societies, bringing back to the state the duty to regulate and to look for the best possible organization of the economy.

In this way, it is important to praise Polanyi's work, as the consequences of his ideas launched many discussions about the place of the economy in society, and also led indirectly to the development of a new way of organizing society: the modern Welfare State. As Block (2000, xxxvi) says “Polanyi's vision depends on expanding the role of government both domestically and internationally (...) For him, a substantial governmental role is indispensable for managing the fictitious commodities.”

\subsection{Polanyi and our times}

There is one last conclusion to which we arrive at, based on Polanyi's work, one we believe is also an expression of desire for the present times. As we emphasized during the whole paper, Polanyi's main

\footnotetext{
${ }^{6}$ Polanyi would return openly to these interests in the 1960's, as the editor of the journal Co-Existence.
} 
concern was to show that the market per se is not a sufficient mechanism to organize the economy as to guarantee the livelihood of the human beings, and that other devices should be developed by the states (and societies) to prevent the market from achieving a complete freedom.

Many scholars in the present times are working towards some developments of Polanyi's ideas in this newly globalized world. It would not be possible to develop here a political agenda based on Polanyi's insights, but we shall mention various important steps made by some of these scholars, and then some conclusions may be suggested.

A very interesting step in that direction has been taken by Frances Stewart (2006) who, in a recent paper asks if we need a New Great Transformation and whether it is possible. Her first answer is affirmative: she says that our world, based on total (neo)liberalism is leading many societies to poverty and to an increase in social inequality, as well as it is producing important harmful consequences for the environment. For her, the many liberalizing reforms that have been made on many poor and developing countries on the nineties, based on the IFI's recommendations, are leading only to sharply rising levels of poverty, while the real benefits of these reforms can be seen only in the developed word.

The second answer, although optimistic, is far more cautious. She says that important steps are being made, like the work of the NGOs and the growing movement of corporate responsibility, but many constraints still exist, like the lack of effectiveness of the global institutions, for example WTO, IFI, World Bank and the United Nations ${ }^{7}$. She is especially concerned with the situation of the developing countries, in which this transformation is more urgent but at the same time more difficult, because

...in countries where the market seems to be failing, associated with high and sometimes rising levels of poverty and stagnant and sometimes falling incomes, one would expect a more robust political challenge. This seems particularly probable where there are democratic institutions - the situation, as noted, in most developing countries today. Yet everywhere the political and economic situation seems to constrain any political challenge to the market to a much greater extent than it did in Europe and the USA in the late nineteenth and early twentieth century (Stewart, 2006, p.16).

Another move in the same direction is made by Brent McClintock \& J. Ronald Stanfield (1991). The authors argue in favor of a cultural New Great Transformation. Their main argument is that our fundamental contemporary problem is the ideology that free markets are always good. They say that while societies still believe that this ideology can show the road to development, the double movement and the disruptive side of the markets will always exist. Their idea is based on Polanyi's concept of the obsolete market mentality (Dalton, 1968), where he emphasize that societies have got an obsolete vision of the market, believing that its total development is always advantageous. According to the authors (McClintock \& Stanfield, 1991, p.59):

From a cultural perspective, the double movement may be seen as a dynamic struggle for dominance between cultural systems. Two antagonistic forces [free market and Welfare State] seek to present competing explanations of the world and justifications of a recommended way of living. The obsolete market mentality is a cultural system that is a conscious effort to establish patterns of

\footnotetext{
${ }^{7}$ Of course, it can be also suggested that the policy prescriptions of these institutions are in some cases contradictory and in other ones really harmful. For a criticism of these institutions see Stiglitz (2002) and Bresser-Pereira (2007).
} 
meaning symbolized by the self-regulating market, equilibrium, efficiency, and material progress mediated by self-interest gain.

In this way, the authors argue that only a cultural transformation, where societies understand the consequences of the free markets and change their ideology towards a welfare culture, can conduct to significant changes in the world. And they believe that this transformation is necessary now.

Other authors that argue in favor of a New Great Transformation are Eric Helleiner (2006) and Björn Hettne (2006). The works of both of them claim that the needs asking for a New Great Transformation are different from the ones of Polanyi's time.

Helleiner defends a transformation based on a new economic order. For him, the need for the first Great Transformation was the continuous expansion of the free market in many nations during the industrial revolution, together with its social consequences. But now, the New Great Transformation is based on a different situation, were the problem is the expansion of the market based on globalization, moving out from the borders of the nation-states. This expansion can be seen in the advancement of free trade, free capital flows and other mechanism that are developing a world market where the role of the nation-states is gradually disappearing. For him, the New Great Transformation is necessary because the countries are losing their capacity to protect their societies. According to this author:

... a crucial difference between the pre-1939 period and the contemporary era is the role of the nation state in both the creation of a global market order and the reaction to it. In the period described by Polanyi, the liberal project and the rise of the countermovements it induced were intricately connected with the growth and consolidation of the nation state. In the contemporary period, the globalization trend as well as the reactions to it appear to be playing a role in undermining the nation-state's strength and legitimacy as a political-economic unit.(Helleiner, 2006, p.27)

Hettne also sees the existence of new economic order from a perspective similar to Helleiner, in which globalization is preventing countries to fight against the unlimited expansion of the free market. And due to this, he argues that the New Great Transformation should be based on strengthening the role of regionalism. For him, Nation-States should unify forces to protect their societies in a regional view. He is not defending the development of economic areas or free market zones fighting against each other. Rather, he defends the development of regional political-economic organizations that help each other in protecting the livelihood of their citizens. For Helleiner, the New Great Transformation is the emergence of a new order, where regionalism is the main concept, and where countries join forces to fight against the disruptive side of globalization. This is what he calls the New Regionalism:

The New Regionalism can be defined as a multidimensional process of regional integration which includes economic, political, social and cultural aspects. It is a package rather than a single policy and goes beyond the free trade market idea: i.e., the interlinkage of previously more or less secluded national markets into one functional economic unit. Rather, the political ambition of establishing territorial control and regime coherence cum identity (in Polanyi's terms, protecting regional civil society) is the primary regionalist goal. (Hettne, 2006, p.69)

One last author that also moves in the same direction is Samir Amin (2006). He also believes that regionalism is the best way to re-launch development. Amin's argument is that liberalism has failed to promote growth and development, but in this new economic order we should not the return to past 
systems such as the Welfare State or socialism, that also showed to be ineffective. In opposition, he advocates that regionalism is also the way to promote development and bring back the control of the economy to the society. Differently from the other authors above mentioned, however, he presents some specific suggestion of policies that should be adopted to develop regionalism and for constructing a new order. He defends policies at the global level and also at the regional level; his main ideas are: (i) to conceive a new World Trade Organization, as an institution that should plan the use of major natural resources, (ii) to organize capital markets as to channel excess finance toward productive investment in the peripheries, (iii) to rethink the international monetary system transforming it into a new one able to articulate regional monetary systems, in a way to promote financial stability across the world (Amin,2006).

Amin`s ideas can be controversial, as the arguments of all other authors that were just cited.

Nevertheless, the main point is not to discuss if their ideas are right or wrong, but to show that this is a step into the discussion of what can be done to change this contemporary situation. More than merely presenting academic arguments, all of them are showing that this discussion needs to be active and real.

We believe that in these days of globalization and neo-liberalism, these concerns raised by Polanyi, and their significance in our times, should be permanently brought back to the discussion so that the problems of human livelihood in our days could be better dealt with.

\section{The development of the fictitious commodities in Brazil: a proposal of analysis}

Polanyi certainly was a creative thinker, and one of his most original contributions is the belief that a “... market economy must comprise all elements, of industry, including labor, land and money” (2001, p.74) because they are essential to its functioning. These elements, however, cannot be considered at the same footing with regular commodities because they are not produced to be sold. We will discuss below the characteristics of each one of these fictitious commodities, but for the moment we just need to emphasize that this perspective raises some fundamental questions, as it considers troublesome to let supply and demand govern the fate of some aspects of human life whose contribution to the material activities of mankind had been always decided according to other criteria. Polanyi noticed that this kind of organization posited some ethical problems ${ }^{8}$, and his own description is loaded with terms pointing in that direction, as when he speaks of the "perils to society" involved in a market economy (p. 75). Perhaps one of the most often reminded phrases of the Great Transformation would suffice to capture his spirit:

Undoubtedly, labor, land and money are essential to a market economy. But no society could stand the effects of such a system of crude fictions even for the shortest stretch of time unless its human and natural substance as well as its business organization was protected against the ravages of this satanic mill (Polanyi, 2001, p.76-7, original emphasis).

It is important to stress that Polanyi's concerns about a market society, as well as ours, should not be read as a romantic or even reactionary defense of pre-capitalist societies. To say that a market society

\footnotetext{
${ }^{8}$ Concerns have been raised about the use of markets to obtain and distribute some "goods and services" (if they can be so considered), as blood for transfusions (or other organs for transplants), care for the ill, the old or the infant, etc. Paradoxes grow even bigger when we consider the possibility to transact in a market the right to vote, or at the simple idea of selling and buying friendship, etc. For an excellent discussion of these issues, see Anderson (1990).
} 
creates a new situation and a new kind of problems for mankind is not the same as to say that all past times were better; what Polanyi meant was in a market society some serious problems appear for the first time in history ${ }^{9}$. So, when discussing below the constitution of these three markets in Brazil, we are not praising any previous forms of organization.

\subsection{Land}

For Polanyi, land is a fictitious commodity, because it is not produced to be bought and sold, but it is just "the natural surroundings in which it [society] exists" (2001, p.75). As Polanyi was studying the English society in the Great Transformation, his focus was placed on the creation of a market for land in that country. He knew, however, that land had been bought and sold there centuries before the beginning of the Industrial Revolution. So, we understand that Polanyi's concern is not the existence of some occasional transactions, but the generalization of the subordination of the use of the land to the market mechanism, in which "the use of land could be negotiated for a price called rent" (2001, p.137), creating a real-estate market.

Polanyi devotes one chapter of the Great Transformation to discuss specifically the commoditization of land. As he says,

One Big Market ... is an arrangement of economic life which includes markets for the factors of production. Since these factors happen to be indistinguishable from the elements of human institutions, man and nature, it can be readily seen that market economy involves a society the institutions of which are subordinated to the requirements of the market mechanism. (Polanyi, 2001, p.187)

It is noteworthy to stress that Polanyi was not, up to this point, concerned with the ecological consequences of the occupation of England (or the whole Europe) that had seriously modified the environment well before the establishment of a market society ${ }^{10}$. Perhaps his main point was that any society needs food (as well as some other natural resources for housing, clothing, etc.), and that land should be used for that purpose; in that sense, the basic problem when land turns into another commodity is that there is no guarantee that its most profitable use will warrant the production of enough food for the population. This concern does not explicitly include any question about the distribution of the products of the land, though reflections about this problem are completely compatible with his fears.

So, when we look into the evolution of the use of land in Brazil using Polanyian lenses, we face the challenge of trying to explain a society whose own origins can be explained basically as a commercial endeavor of the Portuguese crown ${ }^{11}$. We can say that, in this case, the market even precedes the society. So this situation creates a clear contrast with the typical one Polanyi had in mind. In Europe we see how a society which used to have markets just for local exchange of surplus production was threatened by the development of the markets (through enclosures, lack of food production, food exports, etc); in some colonial societies, as in the Brazilian case, from its very beginning the aim of the

\footnotetext{
9 "Neither under tribal nor under feudal nor under mercantile conditions was there ... a separate economic system in society" (Polanyi, 2001, p.74)

${ }^{10}$ Although Polanyi discusses some serious environmental consequences of the evolution of mankind, he mentions them just as examples of the problems created by a market society (2001, p.193).

${ }^{11}$ According to the well-known Brazilian historian Caio Prado Jr., this interest conferred the "meaning of the colonization" (Prado Jr, 1979).
} 
use of land was to export crops, and so the subsistence had to be organized as a necessary complement, in order to sustain the activity for which the land had been occupied. However, this society gained its own dynamic, and years later many of its activities could be explained without any mention of the colonial market relationship.

Since the beginning of its colonization in the first half of the sixteenth Century, all the land of Brazil was owned by the crown, who gave concessions to some aristocrats to occupy big areas through the an institution known as sesmarias ${ }^{12}$. These where given in very large blocks, normally between 60 and 100 square miles, exceptionally as small as 10, but they could even be as big as 300 square miles. These lands, however, could be legally sold after some years, so a relative fragmentation took place.

Although the use of land was basically organized around a commercial endeavor, namely the production of sugar or other tropical crops, it must be kept in mind that land was the most abundant "factor of production" in the colonial period. This pattern did not change later on, when coffee production became the most important activity in an already independent Brazil. Given the abundance of land, to grow foodstuff was something perfectly compatible with the exporting activity. So no tradeoff between a market-oriented production and the subsistence of people, even the poorest ones, ever appeared. Besides, we must remember that this basic pattern of expansion was extremely predatory in relation to the environment (Dean, 1997), but the abundance of land somehow hid this problem.

In parallel, a subsistence economy developed, and an important group of free and mainly poor people grew in the shade of the market-oriented plantations. This combination of poor free people and a landowning elite gave rise to a basic pattern of occupation of the Brazilian territory that has scarcely changed up to our days. As the commercial activities increased, poor landless people settled as squatters (posseiros) in some land in the frontiers of the occupied regions, in which there were no clear property rights. Typically, as any of the cash products later expanded, this land (the occupied plots and much more) would be claimed and legalized by some wealthy people, and the settlers would be pushed farther to the interior. This pattern was consolidated through the Land Act of 1850, which gave formal property to those holding lands without any previous formal title, provided they could prove the productive occupation of the land ${ }^{13}$; the State was to be considered owner of all the non-owned land. This measure created an expectation that ownership of land occupied de facto would be periodically regularized "for the last time", an expectation that got several times confirmed ${ }^{14}$, reinforcing the pattern of expansion.

Questions about the ownership and use of land were not an issue in a slaveholding society in which even many poor free people owned some slaves. Even in regions with a low share of slaves in the population, tensions got somehow accommodated and peasant revolts were a very exceptional issue during the XIXth century. With the end of slavery (1888) and the beginning of the immigration of free labor (especially since the 1880s), the laws orienting this migration prevented the easy access of these newcomers to the land. It is only after this period in which some big peasant revolts began, although some of them were on their surface mainly religious and messianic movements.

Polanyi suggests that the antagonism against the advances of the industrial sector and of free-trade were the cement uniting, in Europe, peasants and big landowners opposed to the merchantilization of

\footnotetext{
12 The first intent of colonization consisted in giving larger traits of land, called Capitanias Hereditarias (Hereditary Captainships), to some aristocrats who would promote a private process of colonization. This idea proved to be a failure and was soon abandoned.

${ }^{13}$ On the Land Act of 1850 and its consequences, we follow Silva (1996).

${ }^{14}$ In that respect, this is not very different from the occupation of some parts of the USA in the late XIXth and early XXth Centuries, according to Nelson (1995, chapter 1).
} 
land. However, in Brazil, a country whose exports were agricultural, free-trade became the ideology of the rural elites ${ }^{15}$. The expansion of the coffee production, the leading sector of the Brazilian economy during the period of the Old Republic (1889-1930), was made simply through the appropriation by wealthy farmers of (mostly free) public land.

Actually, it would be the development of industrialization that would challenge for the first time the characteristics of landownership in Brazil. This is not the place to discuss the alliances that led to the Revolution of 1930, but it suffices to say that it shifted the pendulum of power towards the industrialization of the country. Traditional agriculture began to be considered in two ways: the exports of coffee and other crops (cocoa, sugar, etc) were judged as necessary to obtain foreign currency to finance the industrialization of the country, so no big issues, except some distributional ones, were raised in this area. However, with an increasing migration from rural to urban areas during the industrialization, access to foodstuff increasingly became a crucial issue ${ }^{16}$, and then the first proposals for Agrarian Reform appeared around the 1940s and 1950s, especially with the creation of the Agrarian Leagues. The wished-for class alliances, though, resulted unviable: the proposed union of the industrial bourgeoisie with their workers, the peasants and the rural wage-earners against the landowning elites was more than utopian in a world at the eve of the Cold War. Almost naturally, any attack on property came to be seen as a threat to a capitalist society ${ }^{17}$, despite the characteristic backwardness of the biggest latifundios.

So, one of the first attempts to modernize the economy came through the Land Statute of 1964, adopted by the military government, which sought a "modernization from above", with some policies aimed at the promotion of a more productive agriculture ${ }^{18}$. At the same time, a policy of occupation of the last frontiers was followed according a two-fold strategy: some areas were reserved for the large-scale agriculture, typically for cattle-raising, but other ones were aimed at promoting a familiar agriculture based on small property. Interestingly, this latter policy came as an answer to the pressures of the mid1960s, but it also came in a moment in which the consequences of the commoditization of land became more remarkable ${ }^{19}$.

With the re-democratization, begun in 1985, the different governments that took office from then on were officially concerned with a policy of agrarian reform. Certainly this was influenced by he rise of an important political actor, the Landless Rural Workers Movement (better known by its Portuguese acronym, MST). The results of the different programs is controversial: although some of the governments claim to have achieved the biggest program of Agrarian Reform, the numbers of families settled always came really short of what were avowedly the goals of those programs (Mattei, 2005).

\footnotetext{
${ }^{15}$ A similar phenomenon occurred in the USA before the Civil War, in Argentina all along the XXth Century, etc.

${ }^{16}$ Ignacio Rangel, one of the most important Brazilian economists, proposed that the main cause for the persistent and raising inflation in Brazil in the 1960s were the bottlenecks in food production (Rangel, 1963).

17 The context of the Cold War may lead the reader to understand why the USA favored Land Reform in Japan and Korea at a time in which it was violently opposed to any reform of that kind in South America,

${ }^{18}$ I would not be unfair to remind the historical technological backwardness of Brazilian agriculture. In the XIXth century, and parts of the XXth, even the use of the plow was unusual; a process of slash-and-burn and preparation of the soil with hoes was the most characteristic way of working the land. The spirit, if not the techniques, had not changed too much by the mid 1960s.

${ }^{19}$ An important part of the immigrants to these new areas of small property came from the state of Paraná, in which one of the typical situations feared by Polanyi had recently happened. In this state, whose Northern part was almost unoccupied until the beginning of the XXth century, and in which later the coffee became a monoculture, a combination of a severe frost with falling prices for coffee and raising ones for soybeans led to a replacement of the former plant by the latter from 1976 onwards. Being coffee a labor-intensive crop and soy the opposite, a large mass of rural workers lost their place, and chose to migrate to the new frontier.
} 
Today, we can suggest that the use of land has two basic situations, claiming for two different kinds of actions from the society. On one hand, we have some areas that have been incorporated to the human activities during he last centuries (some of them centuries ago, others just in the last decades), basically at the South, South-East and North-East regions of Brazil; on the other, we have areas at the North and the Center-West, many of them the current frontiers, that have been recently occupied or are even being occupied nowadays. In both cases we believe that a most effective advancement of the proposals of

Agrarian Reform is urgent. The objective would not so much to achieve mainly economic goals, but to support families in the rural areas so as to avoid the continuous migration to the slums on the outskirts not only of the bigger metropolitan areas, but also in medium sized cities, a flux that imposes a heavy burden on those who migrate and also on the municipal authorities (and the whole population) of those cities, whose provision of public utilities increases beyond any control. As for the regions recently incorporated to the economic activities, it is important to use them productively. Many cases of occupation with activities of low productivity, mainly cattle-raising, led to an increase of the deforestation both of the Amazonian forest as well as of the savannas (cerrados). These ecosystems face strong threats, and as it is worthless to cry for what is already gone, we believe, following Homma (2005), that a combination of almost zero expansion of the deforestation should be combined with an improved use of the land already modified by human activities. This must be made compatible, as much as possible, with the sustainable use promoted by the traditional communities (Lima \& Pozzobon, 2005)

\subsection{Labor}

In relation to labor, Polanyi's view that labor must be considered a fictitious commodity can be clearly understood. Actually, labor means human beings, and these should never become a commodity to be transacted in the market. When this happens, many abuses over human lives may occur. For example, thinking within a free-market ideology, any increase in the supply of labor should lead, all things equal, to a necessary reduction of the real wages, not taking into account the size of this wage. But for Polanyi, all labor, actually every person, should receive some income as to guarantee to have a decent life, in order to survive; therefore, a reduction of the wages that prevents the attainment of a decent standard of living should not be welcome. So, in this context, labor should never be transformed into a commodity, otherwise it can generate many dreadful consequences for humankind. Polanyi wrote “...'labor power' cannot be shoved about, used indiscriminately, or even left unused, without affecting also the human individual who happens to be bearer of this peculiar commodity” (Polanyi, 2001, p. 76). In Polanyian terms, we could say that labor should be preserved, to protect the livelihood of every man (Polanyi, 1977)

Labor in Brazil has a very interesting history, one that can be divided in two parts. Before the 1930, labor in Brazil had almost no rights. During the colonial period (1500-1822), slaves represented great part of the labor used in the export crops, and also some of the labor used in other activities. After the independence, Brazil took many years to eliminate slavery; the abolition happened only in 1888, being one of the latest countries to do so. At the same time, especially from 1880 onwards, the country received many immigrants from all over the world, most of them from Europe and Asia, which were running away from poverty or political distress in the beginning of the 20th century. During the period between 1888 and 1930, however, the standards of living and the working conditions did not improve substantially. 
From 1930 on, with President Getulio Vargas, Brazil substantially increased the pace of its industrialization. With the expansion of industry and urbanization, many conflicts with industrial labor started to become apparent. It was in that time that president Vargas created the Brazilian labor laws (introduced in 1943, and better known by the Portuguese acronym, CLT); these laws introduced some important advancements, as the minimum wage, protection against unjustified dismissals as well as the paid holidays; these laws basically have not changed very much until today. The Brazilian labor law constituted in that time is very strong, protecting and offering many benefits to the population in the urban sector of the economy, especially industrial workers. However its enforcement was not strong, and therefore it had only a very indirect impact on the most backward sectors of the labor market and on the rural workers.

The strong protection (protectionism?) of the labor laws, and the costs that it produced for the employers, led to the creation of a dual market - with formal and informal workers ${ }^{20}$. While the formal workers, the minority, are protected from the commoditization of their lives, the informal workers remains with many problems, and can not avoid abuses from the market.

Nowadays, Brazil still has problems to deal with this duality, and the labor market segmentation is very strong. By one side, the more orthodox economists, not much concerned with the fate of the workers, defend the complete liberalization of the labor market, not taking into account that the commoditization process in only going to become even stronger if this happen. On the other side, the government and many heterodox economists still can not provide a good set of policies to allow the inclusion of an increasing number of workers in the formal labor market and to incentive more employment.

Besides the incapacity of policy makers to deal with this problem, the country has developed many important social policies in the last years, mainly by the current left-wing government of President Lula (elected in 2002 and re-elected in 2006). While not directly related to the labor market, these policies can be seen as a counter-movement of society to protect more its citizens, mainly in the informal market, in order to give a response to the labor problems.

In conclusion, Brazilian labor market almost always had problems to deal with the disruptive sides of its commoditization, presenting only some improvements in the last years, but still have a long run in order to promote employment, development and to create a strong counter-movement over the commoditization process.

\subsection{Money}

Money is probably the most difficult fictitious commodity to be analyzed. First of all, it is important to understand why, in Polanyi's opinion, money can be considered a fictitious commodity. When we discuss land and labor while keeping in mind the whole Polanyian interpretation, it is easy to understand why they are considered as such. As we said, land and labor are not produced to be bought and sold, actually they are human life and its environment, crucial aspects of our well-being. So, due to these characteristics, they should not become commodities, in order not to generate disruptive effects to human life. But what about money? Can we consider money as an essential aspect of human life? Polanyi (2001, p.201) himself emphasized this difference: "While the perils threatening land and labor

\footnotetext{
${ }^{20}$ Actually, the criterion according to which one can define what counts as formal or informal labor is the compliance with
} those laws. 
from the maelstrom of the market are fairly obvious, the dangers to business inherent in the monetary system are not as readily apprehended”. Of course the answer is no, money is not the same as labor or land, it is only a mean created by man to help the organization of the economy. Money is only an instrument that helps us to make exchanges and to reduce transactions costs. So, how can money become a fictitious commodity, and how this can have a disruptive effect on business and, consequently, over our lives?

Polanyi provides us with these answers. As we said, money is and should be basically a medium for exchange, a device used to help people in their day-to-day transactions ${ }^{21}$. But does money only play this role in our society? If we look around, we can see that money has become an end in itself, and people look for money not for what money represents - the goods that it can provide - but people are seeking for money only to have more money. When this starts to happen, our means of exchange is transformed into a fictitious commodity. The point here is very simple: money should not be a good to be transacted in the market, it should be only an accessory to the markets of all other goods (Polanyi, 2001). Polanyi explains why money should not be considered as just another commodity:

... actual money, finally, is merely a token of purchasing power which, as a rule, is not produced at all, but comes into being through the mechanism of banking or state finance. None of them [land, labor and money] is produced for sale. The commodity description of land, labor and money is entirely fictitious (Polanyi, 2001, p.75-76)

And what happens when money becomes a fictitious commodity? When this happens, differently from the other two fictitious commodities, that affect directly some individuals and/or their environment, in the case of money its disruptive effects affect the whole economy, mainly its productive side ${ }^{22}$. The free flow of money back and forth without representing any real economic transaction or, in other words, the flow of money on the financial markets, only creates volatility and uncertainty for people, frequently affecting the real economy, creating uncertainty over investments and volatility on many prices. And with this impact, money ends up affecting everybody's life.

Traditional monetary economics usually defines money by three essential characteristics: medium of exchange, unit of account, and store of value. The first corresponds to the fact that money should be used to help exchange and reduce transaction costs. The second relates to the idea that money should be used to help setting the relative prices in the market, as a unified unit of account. The last characteristic commonly used to define money is store of value, giving the idea that money may also be used as a financial asset for people to save for future periods of time. In this definition, money is seen as something that should maintain its value physically over periods of time (Sacks \& Larrain, 1992).

If Polanyi analyzed this modern definition, he would probably agree with it. Problems appear, however, when the third function goes beyond its reasonable boundaries. As far as money is stored by

\footnotetext{
${ }^{21}$ We emphasize the term "basically", because a more sophisticated interpretation we have no space to develop hear would stress that money is an instrument allows the cancelation of social obligations created in a web of creditor-debtor relations. According to Moisseron (2002), thinking of money just as a medium of exchange obscured the monetary relations of the former socialist economies, helping to weaken their performance.

22 The distress created by the commoditization of land and labor in principle affects only part of the society: there are winners and losers in any of these processes. Contrariwise, when money turns into a commodity, problems in the money market affect the society as a whole: there are not winners amidst a monetary crash, when the whole economy collapses. It is worth reminding that when speaking of the environmental problems, however, we may be arriving at a turning point: these problems may not longer affect just those whose plots of land, for example, suffer from desertification, but they can affect the quality of life of the mankind as a whole.
} 
precautionary motives, or if it is kept apart just postponing the acquisition of some expensive item, its function as store of value helps the normal functioning of the economy. If however money is stored only in order to make more money, not using it to buy and sell in the market, we arrive at the situation that concerned Polanyi. And this is exactly what Polanyi was worried about: when money becomes an end in itself, a fictitious market for it is created, disrupting all other markets (Polanyi, 2001). The flows of money in its own market have impacts in the other markets. For example, the market for money defines the exchange rate between countries, and the result is that the exchange rate directly affects the exports and imports of all other markets. So, the volatility of the exchange rate created by the money market is disruptive for all other markets. In this way, money should only be used for exchanges, helping other markets, and other financial assets should be used as store of value for people who seek to save for the future.

John Maynard Keynes, one of the most important economists of all times, proposed a classification of the motives to demand money that can add up with Polanyi's criticism. He suggested that people do keep money (in his terms, have a liquidity preference) out of three basic motives: transactions, precaution and speculation (Keynes, 1982, chapter 13). For him, this third motive had disruptive consequences, and so public policies should be aimed at limiting its possibly dire impact. Besides, when analyzing the role of the financial market over the real economy, he concluded that the performance of those markets was not determined by the performance of the real side of the economy. Essentially those markets were self-referential, based only on the flows of money between financial assets among the participants in those markets, movements only weakly related to the real evolution of the economy. But the problem he saw was that these flows could have had a strong influence on the real economy. For example, he said that a company could receive a massive amount of money but be a company in bad conditions, while in the other side a company with good conditions could not receive any money and go bankrupt. This happen because many times in the financial markets investments are made according to decisions related only to the financial market, decisions only associated to money as and end in itself, for example according to the current share price or expectations of the market over a certain asset price. And many times these decisions do not have any relation to the real situation of the companies being invested. In other words, for Keynes, the real economy ended being influenced by the money flows, and not the opposite. (Keynes, 1982)

Of course Polanyi was not analyzing our contemporary financial markets, but in a more simple way this problems also happen with people in its day-to-day transactions. When money becomes a commodity, its flows influence the real economy, changing the normal exchange of goods and the relative prices, and the consequences over human life are really strong. This is why Polanyi considered money also as a fictitious commodity; he saw that the total lack of control over the money market could result into really dismal consequences.

If we bring these ideas to the present times we can see how these impacts became even more important. In our globalized society, were financial markets are completely integrated and money flows almost everywhere, Polanyi's worries would be even greater nowadays.

Even some important mainstream contemporary economists see these problems in our days; one of them is Paul Krugman. He argues that the financial crisis that took place in the American economy in 2007 only happened because of the lack of regulation over the financial markets by the American government. He argues that without the regulation, money flowed to bad investments, as the subprimes household market, and the consequences were a complete turbulence of the financial market that also impacted over the real American economy. Krugman says "The great sin, of the Fed and also 
of the Bush administration, was not implementing an adult inspection over the markets working without any control” (Krugman, 2008).

But how can this problem be verified in Brazil? In Brazil, during almost all of its industrial development, from the thirties to the seventies, the Brazilian markets were mainly closed to the rest of the world, implementing an import substitution mechanism to promote its industrial development. During all this time, money flows to and outside Brazil were controlled, and during most of the time the exchange regime was one of fixed rates. In other words, the money problem had not much impact in Brazil during all this time.

In the eighties, the import substitution process ended, and Brazil suffered from lack of economic growth and at the same time the chronic problems of inflation went completely out of control. Trying to respond to these problems, and as other developing economies influenced by the suggestion of the socalled (neo-liberal) Washington Consensus, Brazil started to open his economy in the beginning of nineties, opening the economy to imports and to the entrance of capital flows (Bresser-Pereira, 2007a). In 1999, Brazil adopted the floating exchange rate regime, and from that time until now Brazil can be considered an open economy in terms of the flows of money.

Since the openness of the country for financial flows until now we can see a lot of disruptive effects that Brazil is suffering from this complete openness to money flows. In terms of financial impacts, Brazil suffered from all international crisis of the world, in Mexico, East Asia, Russia and Argentina, for example. All these crises, unrelated to the Brazilian economy, impacted over our financial market, generating volatility and turbulence.

But beyond the financial market, the effects of this openness also impacted in the real Brazilian economy. In first place, all the international crises generated uncertainty and lack of investments in the Brazilian economy, resulting in bad years for the country. In second place, since the adoption of the floating exchange rate regime, Brazil suffers from volatility in the exchange rate, resulting in impacts of exports in the real economy. More recently, the Brazilian economy has experienced a real overvalued exchange rate, which is creating extreme hardships for the countries' industrial exports possibly leading to the problem known as Dutch Disease (Bresser-Pereira, 2008).

None of the Brazilian governments since 1995 tried or was able to adopt any effective policy to control these money markets, and so the country today faces lots of trouble to deal with this situation. Some very influential Brazilian economists are discussing the consequences of free capital flows in Brazil and are defending some policies to compensate this ${ }^{23}$. Luis Carlos Bresser-Pereira, for example, argues that free capital flows generate volatility on the exchange rate, for him the most important price of an economy, and this volatility is reflected in the real economy with uncertainty, reductions of investments and exports. He defends that the Brazilian Central Bank should stop using only the interest rate to make monetary policy and starts using capital controls to protect the exchange rate from shocks (BresserPereira, 2007b).

Two other important Brazilian economists, Fernando Cardim de Carvalho and João Sicsú, also defend a similar perspective (Carvalho \& Sicsú, 2004 and 2005). They argue that the myth that free capital flows are necessary for development was created by the Washington Consensus, and it only generated stagnation in Latin-America. They say that capital controls are used by developed economies, even knowing that they are less affected by shocks in comparison with developing economies. So, even

${ }^{23}$ This point had been formerly made in Bresser-Pereira \& Nakano (2002). More information on their perspective is available in Bresser-Pereira's site (www.bresserpereira.org.br). 
without saying with Polanyian terms, they are defending the adoption of capital controls in order to protect the Brazilian economy from money as a fictitious commodity. ${ }^{24}$

Even with some important economists observing the presence of money as a fictitious commodity in Brazil, and defending some practical actions, we believe that the trend of free capital flows is not going to change in the short term, and Brazil will have to deal with these consequences of the role of money as a fictitious commodity for more time.

\section{Conclusion}

Karl Polanyi proposed a new way of looking at our contemporary societies. For him, their main characteristic is the prevalence of the market. Though markets had been present in human experience almost from the beginning of any civilized life, he interpreted that in these former societies the markets had been embedded in society, or, to put it slightly differently, economic activity, even when it was for profit, was limited by the other activities of the society. The novelty of our societies is the disembedding of the economic aspects from the social network in which they typically played a subordinate role.

This process occurred through the metamorphosis into (fictitious) commodities of some things that by their own essence, are not commodities as they were not "produced to be bought and sold", namely, people, their natural surroundings and their tokens for exchange, or, in conventional economic jargon, labor, land and money. For Polanyi, this process threatens to destroy society, and so it is followed (it needs to be followed, better) by a reaction of society placing limits to the unrestricted expansion of markets. Historically, for Polanyi, the civilization of the second half of the nineteenth century tried to create this "stark utopia" of a completely self-regulated market, but the societies that suffered this process reacted, both consciously and unconsciously, and this countermovement was what he considered the great transformation of his time.

It can be said, going one step beyond, that the whole dynamics of the history of our contemporary economies can be understood as a permanent tension between the market, trying to impose its logic on the rest of the society, and the society, trying to place limits to that logic. At the same time, we believe that to read the history of other forms of organization under the same light can be useful, both when applied to pre-capitalist societies (e.g. Wjuniski \& Fernandez, 2008, on the classical Athenian society) as well as to the soviet style socialist societies and their collapse (e.g. Kregel, 2006).

In this paper, we applied this framework to the study of the evolution of the Brazilian society. We focused on the creation of the markets for fictitious commodities in Brazil, stating that it was, from the very beginning, a very different situation from the typical one Polanyi had in mind: actually, the Portuguese colonizers organized the occupation of the Brazilian space through some economic activities that were oriented to the goal of profits in the international markets, and in that sense it can be said that the market came before the society.

We reminded that, for Polanyi, the problem of applying a market logic to the land appeared as the society could face the risk of not having enough foodstuff; besides, that same logic could threaten the survival of some people who previously made their living from working the land but could be unable to maintain this activity any longer. However, when looking at the situation of the use of land in Brazil,

24 Silva, Oreiro \& Paula (2004) also defend similar ideas. 
we proposed that it had always been the abundant factor, so historically only in the past century (especially in its second half) the relative lack of land in some regions became an important social issue. The countermovement came through the appearance of some social movements of the peasants and the rural workers, first thorough the Agrarian Leagues, but in the last years especially trough the MST, which became a very important player in the Brazilian society. We also added that, although it was not explicit in Polanyi's considerations, the worries with the ecological impact of the expansion of the agricultural activities, mainly to the Amazonian rainforest, is in urgent need of a countermovement; the importance of the ecological concerns in Brazil has recently increased significantly, although for the moment not up to the point of placing strong limits to this situation.

As for the labor market, we emphasized that the existence of slavery prevented its creation almost up to the end of the XIX century. Later, as the prevalence of different forms of sharecropping characterized a basically rural society, a typical labor market became mainly an urban issue, especially with the immigration and the beginnings of industrialization. Here the first countermovement came through the constitution of unions and other forms of workers organizations, in which the socialist and anarchist ideologies played an essential role. The Vargas' administration (1930-1945) proposed a paternalistic but at the same time rather effective bundle of social policies, mainly through the implementation of the Labor Laws (CLT). Although the protection guaranteed by these laws was important for the employees of the major firms and the public sector, it was ineffective, however, for a very significant part of Brazilian workers, especially as the urbanization boomed, leading to the creation of an informal market in which these laws were (and still are) ignored. Further labor-protecting legislation was later created, but the gap between both segments of the labor market increased from the 1980's onwards, as the pressures of globalization added to the weak performance of the economy. Only in these last years the situation changed, as the recovery of the economy had a positive impact on the formal labor market bringing to it many workers who were previously in the informal one. Besides, new policies of direct income distribution, which began in Cardoso's government and greatly increased in Lula's one improved the situation of the weakest groups of the labor market.

The money market is certainly the one that presented bigger changes in the last decades, not only in Brazil, but also at the international level. Although the banking and finance in Brazil was rather insignificant up to the early 1960s, a process of expansion began following the impact of the banking Act of 1965. This growth was characterized by its closure to the international money market, leading to the creation of a big (probably oversized) national banking industry. However, in the 1990's the integration and liberalization of the Brazilian finance market occurred, following the movement of the neoliberal tide; all this lead to an increase of the exposure of the Brazilian economy to the humors of the international money markets, as demonstrated by the crisis of 1999 and the recession of 2002-3. We proposed that, in any case, the answers to this process require mainly an effective international countermovement, and therefore strictly national actions are severely impaired. However, we stressed that some measures can be taken at the country level, and proposed that some limits to the capital movements are needed in Brazil. Among other advantages, this could diminish the pressures for a valorization of the Brazilian currency, allowing the Brazilian economy not to suffer from the perils of the Dutch Disease.

We finally emphasize that the Polanyian framework allows interesting insights when applied to the evolution and present situation of the Brazilian society. We finish by quoting Frances Stewart once more, as she suggested that "...the harsh consequences of the market make a new great transformation desirable, but the possibilities of change are severely constrained by global forces” (2006, p.22); we 
believe she is right and, remembering Polanyi's phrase, we consider that the livelihood of the future generations depends on an effective and positive solution to this situation.

\section{References.}

Adaman, Fikret \& Devine, Pat, eds. (2002). Economy and Society: money, capitalism and transition. Montreal: Black Rose.

Amin, Samir (2006). “Conditions for Re-launching Development”. In McRobbie, Kenneth \& Levitt, Kari Polanyi (eds), Karl Polanyi in Vienna. The Contemporary Significance of The Great Transformation. Montreal: Black Rose, p.73-84.

Anderson, Elizabeth (1990). "The ethical limitations of the markets”. Economics \& Philosophy, 6 (2) 179-205.

Block, Fred (2000). "Introduction to The Great Transformation". In Polanyi, Karl (2001) [1944]. The Great Transformation. Boston: Beacon Press. 2nd ed.

--------- (2003). “Karl Polanyi and the Writing of 'The Great Transformation’”. Theory and Society, 32 (3): 275-306.

Bresser-Pereira, Luiz Carlos (2007a). Macroeconomia da estagnação: crítica da ortodoxia convencional no Brasil pós-1994. São Paulo: Ed. 34.

(2007b). “Novo Desenvolvimentismo e Ortodoxia Convencional” in Diniz, Eli, (org.), Globalização, Estado e Desenvolvimento: Dilemas do Brasil no novo milênio. RJ: Editora FGV.

(2008). “The Dutch Disease and its Neutralization: a Ricardian Approach”. Revista de Economia Política, 28 (1).

- \& Nakano, Yoshiaki (2002) “Uma Estratégia de Desenvolvimento com Estabilidade”. Revista de Economia Política, 22 (3): 146-180.

Carvalho, Fernando Cardim de \& Sicsú, João (2004). "Controvérsias Recentes sobre Controles de Capitais". Revista de Economia Política, 24 (2): 163-84.

---------- (2005) "Experiências de controles do fluxo de capitais: focando o caso da Malásia”. Economia e Sociedade, 4 (2): 365-374.

Dean, Warren (1997). With Broadax and Firebrand: The Destruction of the Brazilian Atlantic Forest. Berkeley \& Los Angeles: University of California Press.

Garlipp, José Rubens (2006). "Marx, Keynes, Polanyi e a economia desregrada: três contribuições críticas ao mercado auto-regulado”. Anais do XXXIV Encontro Nacional de Economia ANPEC, Salvador (CD-Rom).

Helleiner, Eric (2006). “Globalization and Haute Finance - Déja Vu?” In McRobbie, Kenneth \& Levitt, Kari Polanyi (eds), Karl Polanyi in Vienna. The Contemporary Significance of The Great Transformation. Montreal: Black Rose, p.12-31.

Hettne, Björn (2006). "Re-Reading Polanyi: Toward a Second Great Transformation”. In McRobbie, Kenneth \& Levitt, Kari Polanyi (eds), Karl Polanyi in Vienna. The Contemporary Significance of The Great Transformation. Montreal: Black Rose, p. 60-72. 
Homma, Alfredo K.O. (2005). “Amazônia: como aproveitar os benefícios da destruição?”. Estudos Avançados, 19 (54): 115-35.

Humphreys, S.C (1969) “History, Economics, and Anthropology: The Work of Karl Polanyi”. History and Theory. Vol.8, No 2, 165-212.

Keynes, John Maynard (1982) [1936]. A Teoria Geral do Emprego, do Juro e da Moeda. Editora Atlas: São Paulo.

Kregel, J. A. (2006). “On the Economic Implications of (Mis)Understanding Markets in Transition Countries”. In McRobbie, Kenneth \& Levitt, Kari Polanyi (eds), Karl Polanyi in Vienna. The Contemporary Significance of The Great Transformation. Montreal: Black Rose, p.108-115.

Krugman, Paul (2008) “Não chore por mim, América”. O Estado de São Paulo, Page B-2, 19/01/2008.

Lisboa, Armando (2000). "A atualidade de Karl Polanyi para a reconstrução do pensamento econômico”. Anais do V Encontro Nacional de Economia Política-SEP, Fortaleza (CD-Rom).

Lima, Deborah, \& Pozzobon, Jorge (2005). “Amazônia socio-ambiental: sustentabilidade ecológica e diversidade social”. Estudos Avançados 19 (54): 45-76.

Mattei, Lauro 2005). “Agrarian Reform in Brazil under Neoliberalism: Evaluation and Perspectives”. In Moyo, Sam \& Yeros, Paris (orgs.), Reclaiming the land: the resurgence of rural movements in Africa, Asia and Latin America. London \& New York: Zed, p. 34-58.

McClintock, Brent \& Stanfield, James Ronald (1991). "The Crisis of the Welfare State: Lessons from Karl Polanyi”. In Mendell, Marguerite \& Salle, Daniel (eds), The legacy of Karl Polanyi: Market, State and Society at the end of the Twentieth Century. NY: St. Martin's Press, 1991.

Moisseron, Jean-Yves (2002). “Money without exchange: theoretical reconsiderations”. In Adaman, Fikret \& Devine, Pat (eds.), Economy and Society: money, capitalism and transition. Montreal: Black Rose, p.134-49.

Nelson, Robert (1995). Public Lands and Private Rights: the failure of scientific management. Lanham (MD): Rowman \& Littlefield.

Polanyi, Karl (1968). Primitive, Archaic and Modern Economies. (Posthumously edited book, organized by George Dalton). New York: Doubleday.

(1977). The Livelihood of Man. (Posthumously edited book, organized by Harry Pearson). New York: Academic Press.

--------- (2001) [1944]. The Great Transformation. Boston: Beacon Press. 2nd ed.

Prado Jr, Caio (1979). Formação do Brasil Contemporâneo. SP: Brasiliense.

Rangel, Ignácio (1963). A inflação brasileira. RJ: Tempo Brasileiro.

Sachs, Jeffrey D. \& Larrain, Felipe B. (1992). Macroeconomics in the Global Economy. New Jersey: Prentice-Hall Inc.

Silva, Guilherme Jonas Costa da ; Oreiro, José Luís \& Paula, Luiz Fernando de (2004) "Fluxos e Controle de Capitais no Brasil: Avaliação e Proposição de Política”. In Paula, Luiz Fernando; Oreiro, José Luiz \& Sicsú, João (orgs.) Agenda Brasil: Políticas Econômicas para o Crescimento com Estabilidade de Preços. RJ: Manole. 
Silva, Lígia Osório (1996). Terras devolutas e latifúndio: efeitos da lei de 1850. Campinas: Ed. Unicamp.

Stewart, Frances (2006). “Do we need a new 'Great Transformation’? Is one likely?”. QEH Working Paper $\mathrm{N}^{\mathrm{o}}$ 136. (Available at http://www3.qeh.ox.ac.uk/pdf/qehwp/qehwps136.pdf; accessed on 15/02/07)

Stiglitz, Joseph (2002). Globalization and its discontents. New York \& London: W.W.Norton.

Tandy, David W., org. (2001). Prehistory and history: ethnicity, class and political economy. Montreal: Black Rose.

Wjuniski, Bernardo S. \& Fernández, Ramón G. (2008). "Karl Polanyi, Athens and us: the contemporary significance of Polanyi's thought”. Anais do XIII Encontro Nacional de Economia Política-SEP, João Pessoa (CD-Rom). 